\title{
S-layer of Lactobacillus helveticus ATCC 12046: isolation, chemical characterization and re-formation after extraction with lithium chloride
}

\author{
Sylvie Lortal, ${ }^{*}$ Jean van HeiJenoort, ${ }^{2}$ Karin Gruber ${ }^{3}$ and Uwe B. Sleytr ${ }^{3}$ \\ ${ }^{1}$ INRA, Laboratoire de Recherches de Technologie Laitière, 65 rue de St-Brieuc, 35042 Rennes cedex, France \\ ${ }^{2}$ CNRS, Centre National de la Recherche Scientifique, Unité de Recherche Associée 1131, Université Paris Sud, \\ 91405 Orsay, France \\ ${ }^{3}$ Zentrum für Ultrastrukturforschung und Ludwig Boltzmann Institut für Molekulare Nanotechnologie, \\ Universität für Bodenkultur, 1180 Vienna, Austria
}

(Received 28 August 1991; revised 21 October 1991; accepted 5 November 1991)

\begin{abstract}
In a previous study, electron microscopic examinations of thin sections of Lactobacillus helveticus ATCC 12046 revealed a three-layered structure of the cell wall. The outermost component was identified as a layer of a nonglycosylated $52 \mathrm{kDa}$ protein. Freeze-etched preparations of intact cells have now demonstrated that this protein layer is an oblique surface layer (S-layer) lattice $\left(a=4.5 \mathrm{~nm}, b=9.6 \mathrm{~nm}, \gamma=77^{\circ}\right)$ which completely covers the cell surface. Treatment with $5 \mathrm{M}-\mathrm{LiCl}$ extracted the S-layer protein from intact cells efficiently and selectively. Viability did not decrease significantly. Moreover, the S-layer reappeared when treated cells were allowed to grow again. In vitro self-assembly products obtained upon aggregation of isolated S-layer subunits exhibited the same oblique S-layer symmetry as observed on intact cells in vivo. The purified S-layer protein had a high content (44\%) of hydrophobic amino acids. The $\mathrm{N}$-terminal sequence was mainly composed of alanine, threonine, asparagine and aspartic acid.
\end{abstract}

\section{Introduction}

Crystalline surface layers (S-layers) are a common feature among eubacteria and archaeobacteria (Kandler \& König, 1985; Sleytr \& Messner, 1988; Messner \& Sleytr, 1992). They are composed of identical subunits consisting of a single protein species, which may be glycosylated, and completely cover the cell surface (Beveridge, 1981; Sleytr \& Messner, 1983; Koval, 1988). The biological functions of S-layers in eubacteria include protection, cell adhesion and surface recognition (Beveridge, 1981; Smit, 1986; Gruber \& Sleytr, 1991).

Lactobacillus helveticus has great technological significance, particularly in cheese making (Accolas et al., 1980; Turner et al., 1983). In previous work (Lortal et al., 1991) the cell wall of $L$. helveticus ATCC 12046 was found to have a three-layered structure. The external layer was shown to be composed of a $52 \mathrm{kDa}$ protein, non-covalently linked to the internal layers. These results strongly suggested the presence of an S-layer on $L$.

\footnotetext{
- Author for correspondence. Tel. 9928 5334; fax 99285350.

Abbreviations: $\mathrm{CE}$, crude extract; $\mathrm{GHCl}$, guanidinium hydrochloride; PCF, polycationic ferritin; S-layer, surface layer.
}

helveticus ATCC 12046, especially since an S-layer has been detected on other strains of $L$. helveticus by Masuda \& Kawata (1983).

In this paper the presence of an S-layer on L. helveticus ATCC 12046 was confirmed by analysis of the cell surface topography using freeze-etching techniques. Isolation procedures and reassembly experiments in vitro are described as well as re-formation of the S-layer on intact cells after extraction. The amino acid composition and the $\mathrm{N}$-terminal sequence of the purified S-layer protein were determined.

\section{Methods}

Bacterial strain and growth conditions. Lactobacillus helveticus ATCC 12046 was obtained from the Pasteur Institute, Paris, France, and stored at $-30^{\circ} \mathrm{C}$ in MRS broth (De Man et al., 1960) containing $15 \%$ $(\mathrm{v} / \mathrm{v})$ glycerol. The strain was grown unstirred in MRS medium at $43^{\circ} \mathrm{C}$ after inoculation with $1 \%(\mathrm{v} / \mathrm{v})$ overnight culture.

Determination of the effect of $\mathrm{LiCl}$ and guanidium hydrochloride $(\mathrm{GHCl})$ treatment on cell viability. Viability was determined as c.f.u. on MRS agar plates after incubation for $48 \mathrm{~h}$ at $43^{\circ} \mathrm{C}$ under anaerobic conditions. Exponential-phase cells $\left(1.6 \mathrm{mg}\right.$ dry mass $\mathrm{ml}^{-1} ; 6.5 \times 10^{9}$ c.f.u. $\mathrm{ml}^{-1}$ ) were incubated for $15 \mathrm{~min}$ at several temperatures with $\mathrm{LiCl}$ or guanidinium hydrochloride $(\mathrm{GHCl})$ to extract the S-layer 
protein. The treated bacteria were recovered by centrifugation, washed once in sterile distilled water and resuspended in the initial volume of MRS broth for the determination of viable bacteria by plate counting.

Extraction of the S-layer protein with $\mathrm{LiCl}$ and S-layer re-formation on growing cells. Exponential-phase cells were harvested and washed once with distilled water. Ten-fifteen $\mathrm{mg}$ of the moist pellet were suspended per $\mathrm{ml}$ of $5 \mathrm{M}-\mathrm{LiCl}$ and kept at $0^{\circ} \mathrm{C}$ for $15 \mathrm{~min}$, followed by centrifugation $(30000 \mathrm{~g}, 15 \mathrm{~min})$. The supernatant was designated the crude extract (CE). The pellet of $\mathrm{LiCl}$-extracted cells was washed once in distilled water, resuspended in prewarmed $\left(43^{\circ} \mathrm{C}\right) \mathrm{MRS}$ broth to an $\mathrm{OD}_{650}$ of 0.5 (corresponding to $0.2 \mathrm{mg} \mathrm{dry}^{\mathrm{wt} \mathrm{ml}}{ }^{-1}$ ) and incubated at $43^{\circ} \mathrm{C}$. An aliquot was kept at $4^{\circ} \mathrm{C}$.

Purification of the S-layer protein. The CE was dialysed against distilled water overnight at $4^{\circ} \mathrm{C}$. For analysis of the amino acid composition, a more extensive purification of the S-layer protein was carried out by gel permeation chromatography: the CE was applied to a column $(2.5 \times 50 \mathrm{~cm})$ of Sephacryl S200 (Pharmacia) equilibrated in $5 \mathrm{M}-\mathrm{LiCl}$. Upward elution was done at a flow rate of $50 \mathrm{ml} \mathrm{h}^{-1}$ and fractions of $5 \mathrm{ml}$ were collected. Protein was determined by the Lowry method using BSA as standard. Amino acid analysis was performed with a Pharmacia LKB Alpha Plus instrument as described by Lortal $e t$ al. (1991).

Preparation of cell walls. Cell walls were prepared by mechanical disruption of whole cells using a French press as described by Lortal $e t$ al. (1991).

Electron microscopy and labelling with polycationized ferritin. Negative staining was obtained by treating the grids for $2 \mathrm{~min}$ with a drop of uranyl acetate $(2 \%, w / v$, in distilled water). Thin sectioning was performed as described by Lortal et al. (1991). Freeze-fracturing, freeze-etching and optical diffraction procedures for determining lattice constants are described by Messner et al. (1984) and Pum et al. (1989). For freeze-drying preparations, the pioloform-coated gold grids (400 mesh) were glow-discharged (CTA 010, Balzers) and treated with poly-L-lysine $\left(M_{\mathrm{r}} 56000\right.$, Sigma, $0.1 \%$ in distilled water) for $10 \mathrm{~min}$ to produce a positively charged surface. After floating upside down on the bacterial suspension for $10 \mathrm{~min}$, the grids were washed three times in distilled water and moved onto a drop of polycationic ferritin (PCF, Sigma), incubated for $10 \mathrm{~min}$ and washed three times in $0.05 \mathrm{M}$ Tris/ $\mathrm{HCl}$ buffer, $\mathrm{pH} 7 \cdot 2$. The grids were blotted onto wet filter paper for $45 \mathrm{~s}$ (Kistler et al., 1977) after washing in distilled water to remove residual buffer. The grids were immediately frozen by plunging into liquid nitrogen and were mounted onto a precooled freeze-drying table of a Balzers BAF 400 freeze-etching machine. After freeze-drying at $-80^{\circ} \mathrm{C}$ for $1 \mathrm{~h}$ the samples were shadowed unidirectionally with $2 \mathrm{~nm}$ platinum at an angle of $45^{\circ}$. The heavy metal shadow was reinforced with a $15 \mathrm{~nm}$ carbon layer deposited at an angle of $90^{\circ}$ (Pum et al., 1989). The preparations were first rinsed in acetone and then incubated in chloroform (both from Merck) at room temperature for $3 \mathrm{~h}$ followed by an overnight treatment with $30 \%(\mathrm{v} / \mathrm{v})$ chromic acid at $37^{\circ} \mathrm{C}$. After four washes in distilled water the grids were air-dried. Electron microscopy was performed with a Philips EM 301 microscope using an acceleration voltage of $80 \mathrm{kV}$.

SDS-PAGE. (i) For determination of the apparent molecular mass of the S-layer protein and for electroblotting experiments, SDS-PAGE was performed using a $15 \%(\mathrm{w} / \mathrm{v})$ acrylamide separating gel $(15 \times 15 \mathrm{~cm})$ as described by Lortal et al. (1991). Molecular mass standard proteins were obtained from Pharmacia.

(ii) For all other experiments, SDS-PAGE was performed using a $10 \%$ acrylamide separating gel $(8 \times 8 \mathrm{~cm})$ and a $4 \%$ acrylamide stacking gel. Samples of whole cells (equal weights when comparison between lanes was required), cell walls or isolated $S$-layer protein were suspended in a $3 \%(\mathrm{w} / \mathrm{v})$ SDS solution in $0.05 \mathrm{~m}$-Tris/HCl buffer,
pH 7.2, and treated for $10 \mathrm{~min}$ in a boiling water bath; then the samples were centrifuged and $25 \mu \mathrm{l}$ of the supernatant was mixed with $40 \mu \mathrm{l}$ of the following solution: $0 \cdot 1 \% \mathrm{SDS}, 0 \cdot 1 \% 2$-mercaptoethanol, $30 \%(\mathrm{w} / \mathrm{v})$ glycerol, $0.2 \%$ Orange $\mathrm{G}$ in $0.01 \mathrm{M}$-Tris/ $\mathrm{HCl}$ buffer, $\mathrm{pH} 7 \cdot 2$. Gels were stained with Coomassie blue G250.

Electroblotting and $N$-terminal sequence. Immediately following SDSPAGE, the proteins were electrohoretically $(50 \mathrm{~V}, 1.25 \mathrm{~h})$ transferred to an Immobilon sheet (PVDF 0.45 $\mu \mathrm{m}$, Millipore). The membrane was stained for $30 \mathrm{~s}$ with a solution composed of $0.1 \%(\mathrm{w} / \mathrm{v})$ amido black, $45 \%(v / v)$ methanol and $7 \%(v / v)$ ethanol in distilled water, and washed once in distilled water. The area of the membrane containing the $52 \mathrm{kDa}$ protein was cut out with a sterile scalpel and kept at $-20^{\circ} \mathrm{C}$ until microsequencing was performed with a gas-phase analyser at the Institute of Neurophysiology at the CNRS, Gif sur Yvette, France.

Treatment of intact cells with lytic enzymes. Lysozyme and mutanolysin (both from Sigma) were dissolved before use in $0.05 \mathrm{M}$ Tris/HCl buffer (pH 7.2) and kept at $4{ }^{\circ} \mathrm{C}$. The effect on the bacteria was followed by the decrease in $\mathrm{OD}_{650}$ of a cell suspension in Tris/ $\mathrm{HCl}$ buffer, $\mathrm{pH} 7.2$, at $37^{\circ} \mathrm{C}$. The concentration of the buffer was $0.05 \mathrm{M}$ for mutanolysin and $0.1 \mathrm{M}$ for lysozyme; concentrations of the enzymes are indicated in the Figure legends or in the text.

\section{Results}

\section{Morphological characterization of the S-layer}

Freeze-etched preparations of whole cells of $L$. helveticus ATCC 12046 (Fig. $1 a, b$ ) revealed the presence of a crystalline array which completely covers the cell surface. A clear fracture plane between the peptidoglycan-containing layer and the S-layer could frequently be observed in oblique fracture faces along the cell envelope (Fig. $1 b$ ). In such areas [indicated by the arrowheads in Fig. 1(b)] the thin outermost S-layer can clearly be recognized. In thin sections (Fig. 1c) the S-layer appeared only approximately $9 \mathrm{~nm}$ thick, whereas the underlying layer was three- to four-times as thick. Optical diffraction experiments (Fig. $4 b$ ) with selfassembly products of the $52 \mathrm{kDa}$ S-layer protein showed that the length of the lattice base vectors were 4.5 and $9.6 \mathrm{~nm}$, respectively, with an interaxial angle $\gamma$ of $77^{\circ}$.

\section{Isolation, purification and chemical characterization of the S-layer protein}

Previous work (Lortal et al., 1991) showed that the outermost layer of the cell wall was composed of a nonglycosylated $52 \mathrm{kDa}$ protein. In this investigation, several procedures for extracting the S-layer protein from whole cells and isolated cell walls were tested (Table 1). Since the S-layer protein represented approximately $14 \%$ of the total protein content of the bacteria and gave a dominant band on SDS electrophoretograms (Fig. 2, lane A), the efficiency of the various extraction procedures could be followed by SDS-PAGE (data not shown). 

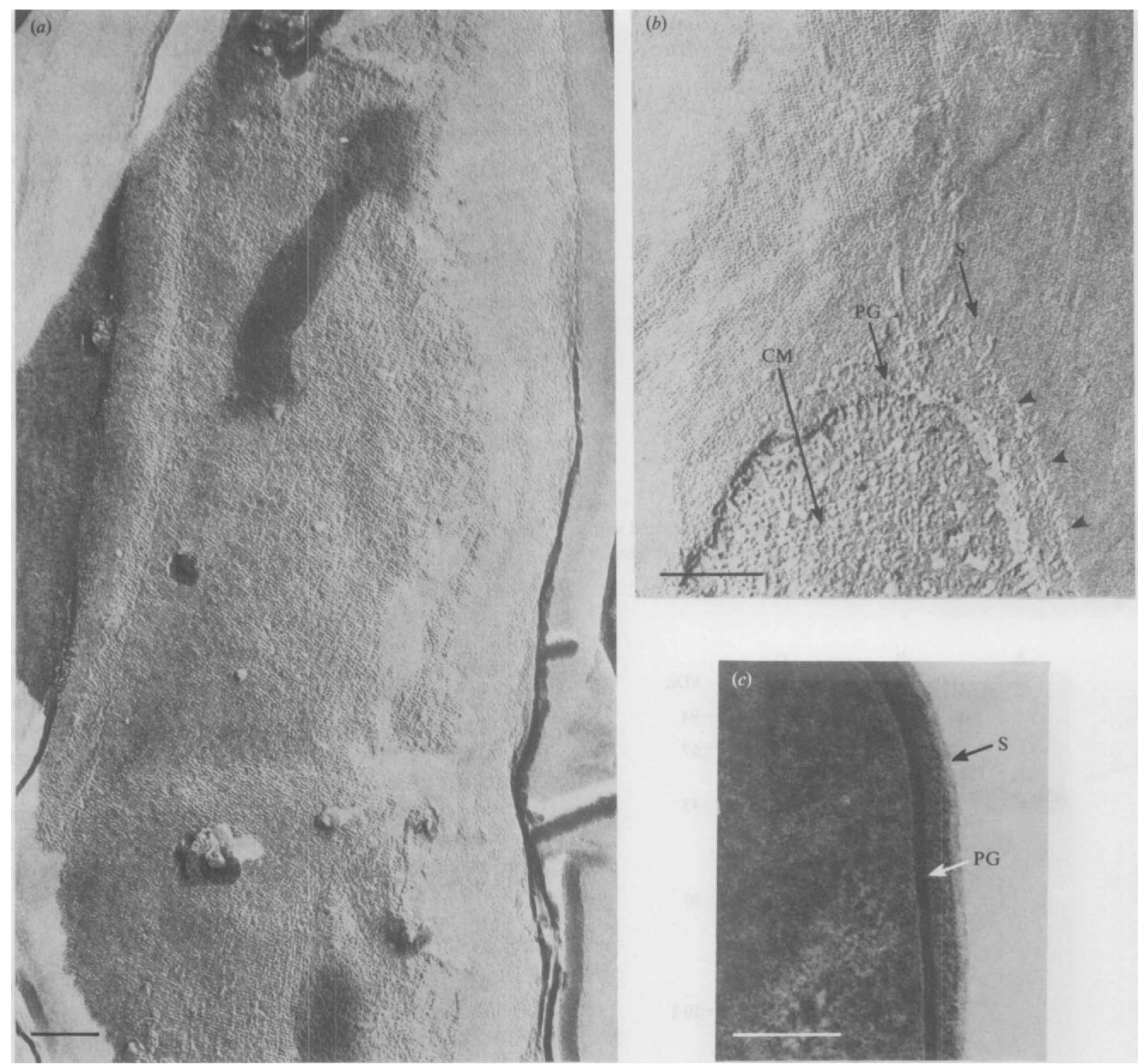

Fig. 1. (a) Freeze-etched preparations of whole cells of L. helveticus ATCC 12046 exhibiting an oblique (p2) S-layer lattice which completely covers the cell surface. (b) Oblique fracture faces of the cell envelope revealing a thick peptidoglycan-containing layer (PG) and a thin S-layer (S); CM, concave fracture face of the cytoplasmic membrane. (c) Thin section of whole cells of $L$. helveticus ATCC 12046; note the thin S-layer [abbreviations as for $(b)$ ]. Bars, $0 \cdot 1 \mu \mathrm{m}$.

Tween 80 , varying concentrations of urea and heating for $15 \mathrm{~min}$ in $0.1 \mathrm{M}$-sodium phosphate buffers at $50^{\circ} \mathrm{C}$ (pH 5, 6, 7.5, 9) were inefficient. $\mathrm{HCl}(0 \cdot 1 \mathrm{M})$ had an extractive effect but also led to hydrolytic damage of the S-layer protein. SDS, $\mathrm{GHCl}$ and $\mathrm{LiCl}$ were found to be efficient extraction agents. Among them, $\mathrm{LiCl}(5 \mathrm{M}$, $15 \mathrm{~min}, 0^{\circ} \mathrm{C}$ ) was the most selective (Fig. 2, lane B) and was therefore chosen for further assays. Lower concentrations of $\mathrm{LiCl}(1$ and $2.5 \mathrm{M})$ extracted less protein. A linear relationship was observed between the concentration of $\mathrm{LiCl}$ and the quantity of protein solubilized. Repeated $\mathrm{LiCl}$ treatment had an insignificant effect on the increase in efficiency of extraction (Fig. 2, lane C).

During dialysis of the $\mathrm{LiCl} \mathrm{CE}$ against distilled water at $4{ }^{\circ} \mathrm{C}$, a white precipitate appeared which could be recovered by centrifugation. The supernatant (Fig. 3, lane $A$ ) revealed some contaminant proteins whereas the white pellet (Fig. 3, lane B) contained mainly the $52 \mathrm{kDa}$ 


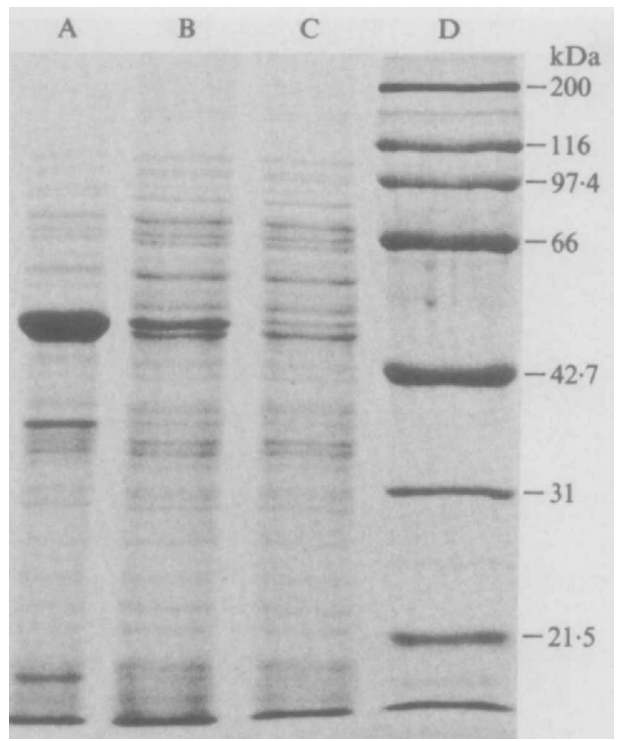

Fig. 2. SDS-PAGE. Lanes: A, whole cells; B, whole cells treated with $5 \mathrm{M}$-LiCl once; $\mathrm{C}$, whole cells treated with $5 \mathrm{M}$ - $\mathrm{LiCl}$ twice; D, molecular mass standards.

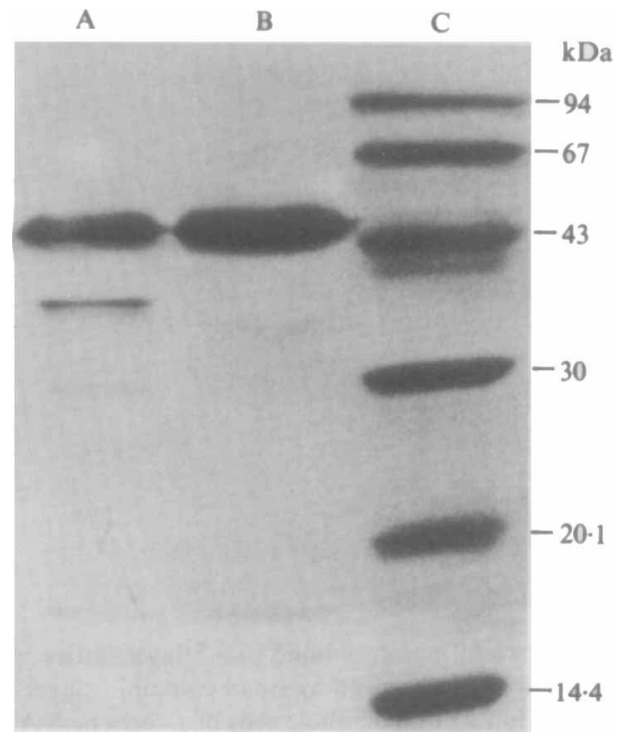

Fig. 3. SDS-PAGE of (A) the supernatant and (B) the pellet obtained upon centrifugation of the dialysed $\mathrm{LiCl}$ crude extract. Lane $\mathrm{C}$, molecular mass standards.

protein and was therefore regarded as pure enough for analysis of its $\mathrm{N}$-terminal sequence. In the sequence obtained - ATTINADSAINANTNAKYDVDVT alanine, threonine, asparagine and aspartic acid accounted for $70 \%$ of the amino acids. Negative staining revealed that the precipitated material obtained during dialysis of the $\mathrm{LiCl}$ extract was reassembled S-layer
Table 1. Effect of various chemical treatments on the S-layer of L. helveticus ATCC 12046

Each treatment was applied at $0^{\circ} \mathrm{C}$ for $10 \mathrm{~min}$, except where otherwise indicated. r.t., Room temperature.

\begin{tabular}{lcc}
\hline \hline \multicolumn{1}{c}{ Treatment } & Whole cells* & Cell walls* \\
\hline Tween $80(5 \%)$ & - & - \\
Urea $(1 \mathrm{M})$ & - & $+/-$ \\
Urea $(3 \mathrm{M})$ & - & $+/-$ \\
HCl $(0 \cdot 1 \mathrm{M}) \dagger$ & + & + \\
LiCl $(5 \mathrm{M}, 15 \mathrm{~min})$ & + & + \\
GHCl $(5 \mathrm{M}, 15 \mathrm{~min})$ & + & + \\
SDS $(1 \%$, r.t., 30 min $)$ & + & + \\
SDS $(1 \%, 100 \%$ C $5 \mathrm{~min})$ & + & + \\
\hline \hline
\end{tabular}

-+ , Solubilization of S-layer protein; -, no effect.

$\dagger$ The S-layer protein was clearly degraded by this treatment.

protein (Fig. 4a). Optical diffraction analysis of electron micrographs (Fig. $4 b$ ) revealed that the sheet-like selfassembly products had the same oblique lattice as observed in freeze-etched preparations of intact cells (Fig. 1a). Purification of the S-layer protein was carried out on a Sephacryl S-200 column. The first peak eluted consisted of the $52 \mathrm{kDa}$ protein, as verified by SDSPAGE (data not shown). The combined fractions were dialysed against distilled water and the precipitated protein was dried overnight using a speed vacuum centrifuge (Savant Instruments). After hydrolysis, the amino acid composition of the protein was determined. As summarized in Table 2, the hydrophobic amino acids accounted for $44 \%$ of the amino acid residues present.

\section{Effect of $\mathrm{LiCl}$ and $\mathrm{GHCl}$ treatment on viability}

Treatment of bacteria with $5 \mathrm{M}-\mathrm{LiCl}$ led to a limited loss of viability $(80 \%$, i.e. $<1 \log$ unit $)$ whereas the extraction with $5 \mathrm{M}$-GHCl led to a drastic loss of viability $(6.2 \mathrm{log}$ units). On repeated treatment with $5 \mathrm{M}-\mathrm{LiCl}$, viability decreased significantly (3.2 log units). For all treatments, results were the same whether the procedures were performed at $0{ }^{\circ} \mathrm{C}$ or at room temperature.

\section{Reformation of the S-layer after extraction with $\mathrm{LiCl}$}

LiCl-treated cells (sample B, Fig. $5 a$ ) incubated at $43^{\circ} \mathrm{C}$ in MRS broth, grew again as shown in Fig. 5(a). Sample A (untreated cells) and samples B-K harvested at different times, as shown in Fig. 5(a), were analysed by SDS-PAGE (Fig. 5b), and labelled with PCF and freezedried for electron microscopical observations (Fig. 6). Hardly any PCF absorbed to S-layer-carrying cells (Fig. $6 a$ ). This implies that the surface of the S-layer is not negatively charged. However, PCF formed a dense layer 

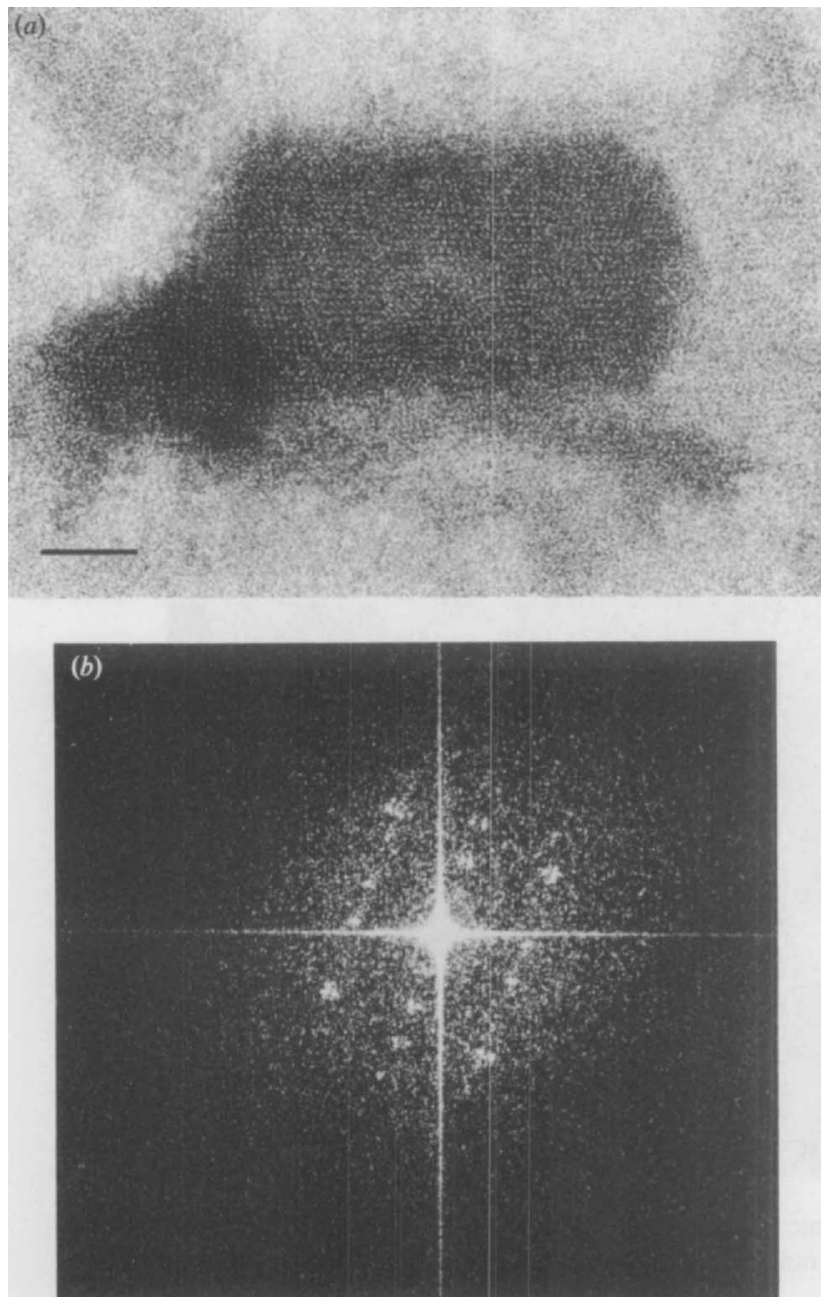

Fig. 4. (a) Negative staining of the S-layer self-assembly product obtained upon dialysis of the $\mathrm{LiCl}$ cell extract (bar, $0.05 \mu \mathrm{m}$ ). (b) Diffraction pattern from S-layer self-assembly product reflecting the oblique symmetry of the crystalline lattice.

on the surface of cells from which the S-layer had been removed (Fig. $6 b$ ). This confirmed the complete extraction of the S-layer by $\mathrm{LiCl}$. As PCF does not absorb onto the S-layer, Fig. 6(c) and $(d)$ suggested that the binding of PCF molecules was prevented by the progressive reformation of the S-layer on $\mathrm{LiCl}$-treated cells of L. helveticus ATCC 12046.

Sensitivity of cells to lytic enzymes before and after removal of the S-layer

To investigate a potential protective role for the S-layer against muramidases, whole cells before and after $\mathrm{LiCl}$ treatment were exposed to lysozyme and mutanolysis.. $\mathrm{LiCl}$ treatment did not increase sensitivity to lysozyme,
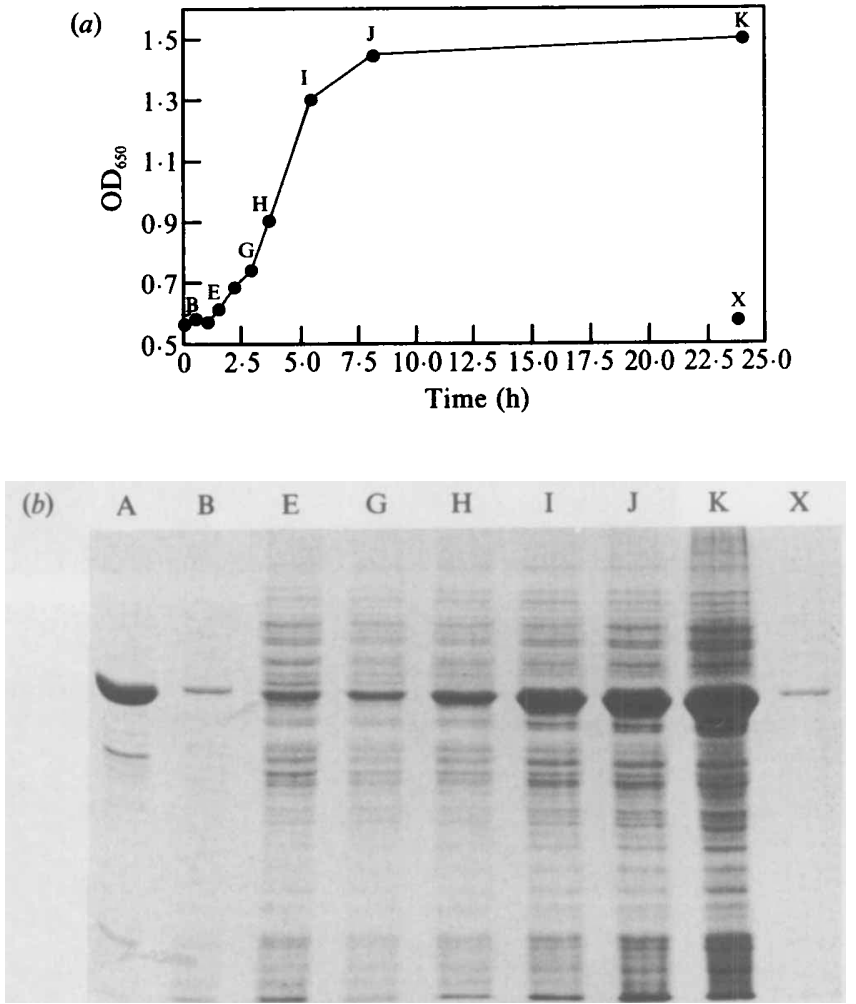

Fig. 5. (a) Growth $\left(\mathrm{OD}_{650}\right)$ of LiCl-treated whole cells (B) after suspension in MRS broth at $43{ }^{\circ} \mathrm{C}$; sample $X$ was kept at $4{ }^{\circ} \mathrm{C}$ and did not grow. (b) SDS-PAGE of whole cells harvested at different times $(B-K)$ indicated on the growth curve in $(a)$, showing the reappearance of the $52 \mathrm{kDa}$ S-layer protein. Lane A corresponds to untreated whole cells; lane $\mathbf{X}$ corresponds to sample $\mathbf{X}$.

Table 2. Amino acid composition of the $S$-layer protein

\begin{tabular}{cc}
\hline \hline Amino acid & Molar ratio (\%) \\
\hline Asx & $14 \cdot 15$ \\
Ala & $11 \cdot 4$ \\
Thr & $11 \cdot 1$ \\
Lys & 10.9 \\
Ser & $9 \cdot 5$ \\
Gly & $8 \cdot 75$ \\
Val & 7.9 \\
Glx & $7 \cdot 35$ \\
lle & 4 \\
Pro & $3 \cdot 8$ \\
Leu & 3 \\
Tyr & 3 \\
Phe & $2 \cdot 4$ \\
Arg & $1 \cdot 45$ \\
His & $1 \cdot 1$ \\
Met & $0 \cdot 2$ \\
Cys & 0 \\
Try & ND \\
\hline \hline
\end{tabular}

ND, Not determined. 

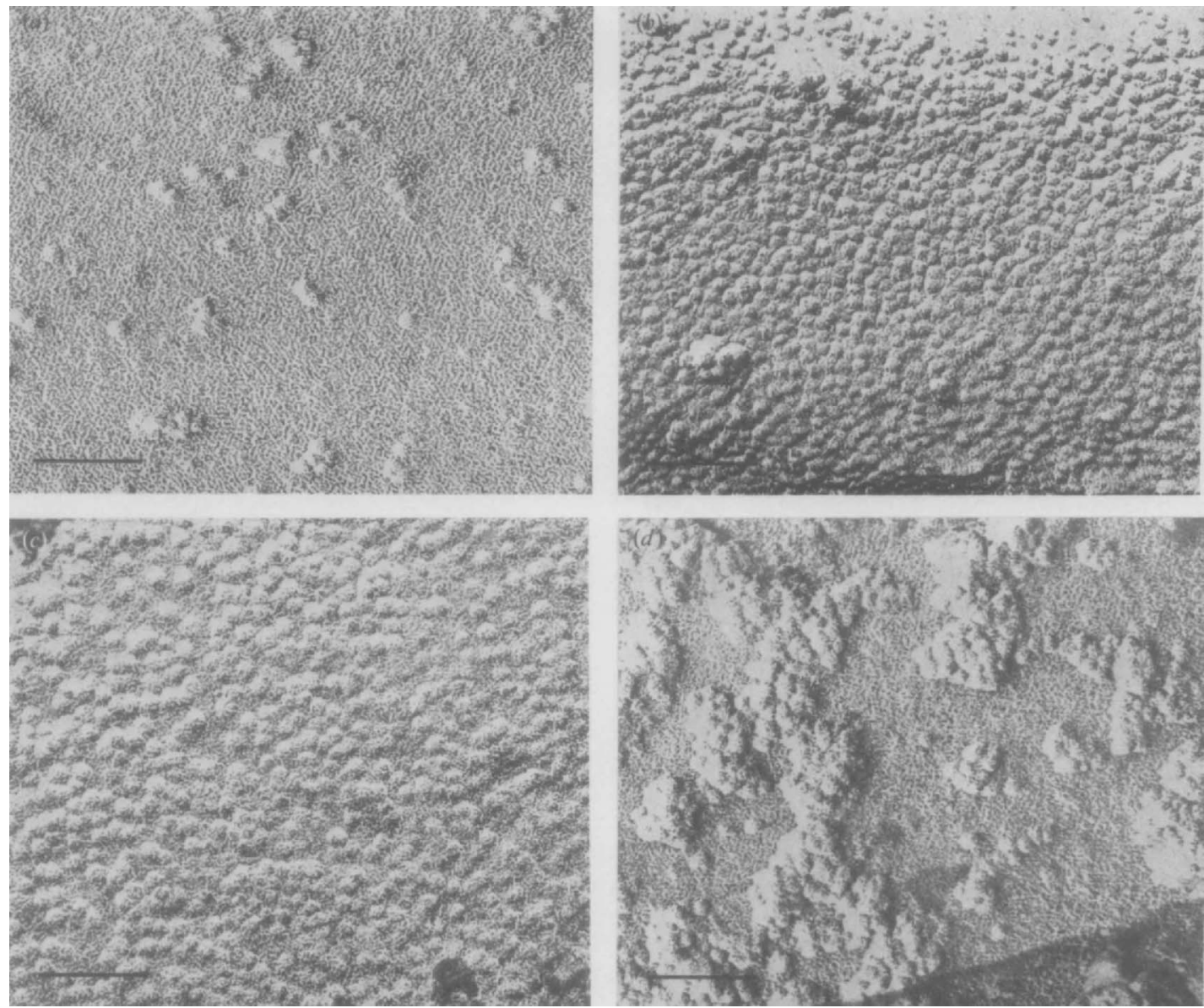

Fig. 6. Freeze-dried preparations of whole cells labelled with polycationic ferritin (PCF). (a) Untreated cells, (b) LiCl-treated cells, and $(c, d)$ stationary phase cells $\mathrm{J}$ and $\mathrm{K}$ (Fig. 5a), respectively. The reappearance of the $\mathrm{S}$-layer is shown by the concomitant decrease of the number of bound PCF molecules. Bars, $0 \cdot 1 \mu \mathrm{m}$.

whereas mutanolysin had a more rapid lytic effect on cells devoid of an S-layer (Fig. 7).

\section{Discussion}

The presence of an oblique S-layer on the external surface of $L$. helveticus ATCC 12046 was clearly established by freeze-etching and negative staining. This has extended our previous work (Lortal et al., 1991) where the more external layer of the cell wall was shown to consist of a $52 \mathrm{kDa}$ non-glycosylated protein, noncovalently bound to other cell wall constituents. Other strains of $L$. helveticus have also been found to contain an S-layer (M. Sàra, personal communication). Masuda \& Kawata (1983) found an S-layer in other $L$. helveticus strains.

Although several studies of the structure and chemical composition of the cell walls of lactobacilli have been performed (Baddiley \& Davison, 1961; Ikawa \& Snell,

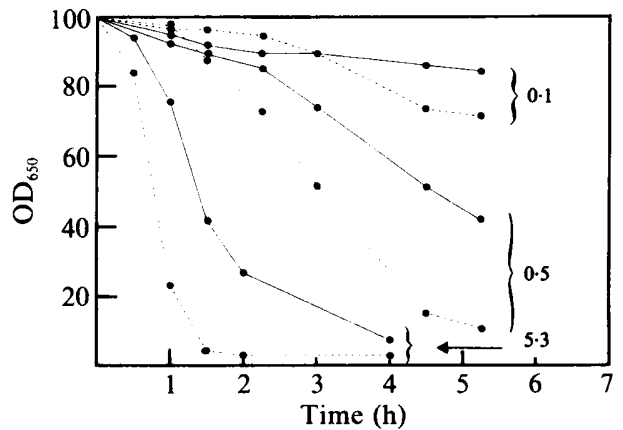

Fig. 7. L. helveticus ATCC 12046 cells, untreated $(-)$ or $\mathrm{LiCl}-$ extracted (------), were tested for their susceptibility to the lytic action of mutanolysin at the final concentrations indicated $\left(\mu \mathrm{g} \mathrm{ml}^{-1}\right)$ in $0.05 \mathrm{M}$ - Tris/ $\mathrm{HCl}$ buffer, $\mathrm{pH} 7.2$.

1960; Williams, 1971), only two strains have been investigated using freeze-etching techniques: Lactobacillus fermenti (Kawata et al., 1974) and Lactobacillus brevis (Masuda \& Kawata, 1979). These displayed 
regular arrays with oblique symmetry like $L$. helveticus. Release of the S-layer protein from isolated cell walls of $L$. fermenti was achieved by enzymic hydrolysis of the peptidoglycan and from $L$. brevis by extraction with $\mathrm{GHCl}$, urea and SDS. Negative staining and electrophoresis also revealed S-layers on $L$. casei (Barker \& Thorne, 1970), L. brevis (Masuda \& Kawata, 1980, 1983), L. buchneri, L. acidophilus and L. bulgaricus (Masuda \& Kawata, 1981, 1985). For all these lactobacilli the apparent molecular mass of the S-layer protein was in the range 41-52 kDa.

We found that it was possible to extract the S-layer protein from whole cells of $L$. helveticus directly at a remarkably high concentration compared to other proteins using $5 \mathrm{M}-\mathrm{LiCl}$. During the removal of the $\mathrm{LiCl}$ by dialysis, the S-layer subunits reassembled spontaneously into sheets with the same p2 symmetry and lattice constants as observed in vivo, showing that they were not substantially altered by the $\mathrm{LiCl}$ treatment. Reattachment experiments with isolated S-layer subunits on naked peptidoglycan-containing layers of $L$. helveticus ATCC 12046 have not been performed although studies on homologous or heterologous reattachment with S-layers from other lactobacilli have provided interesting data on the reattachment of S-layers amongst different organisms (Masuda \& Kawata, 1985). In agreement with data on S-layers from other bacterial species (Masuda \& Kawata, 1983; Sleytr \& Messner, 1988), the S-layer protein of $L$. helveticus had a high content of hydrophobic amino acids and no or very little sulphur-containing amino acids. As observed by Luckevitch \& Beveridge (1989), no homology between the N-terminal sequence determined here and that from other S-layer proteins was evident.

$\mathrm{The} \mathrm{LiCl}$ procedure used in this work for extracting the S-layer protein of $L$. helveticus is a new and interesting alternative to the classical methods with $\mathrm{GHCl}$ or SDS. Electron microscopy, electrophoresis and chemical analysis demonstrated the efficiency and selectivity of this method. Moreover, $\mathrm{LiCl}$ was less lethal than $\mathrm{GHCl}$ to the bacteria. One of the most interesting features was the reformation of the S-layer after its removal. The new S-layer material appeared during the exponential-phase on the cell surface in a random distribution. The change in the mode of distribution of the PCF molecules from Fig. $6(c)$ to $6(d)$ could be interpreted as a 'charge drift'. Pushed or partially masked by growing and fusing crystallites of the newly synthesized S-layer protein, the long teichoic acid molecules protruding from the peptidoglycan layer could form areas of high negative charge in the closing S-layer. For two Bacillus species (Gruber \& Sleytr, 1988; Howard et al., 1982), the incorporation of newly synthesized S-layer protein into a coherent S-layer lattice has been shown to be non-random. However, the S-layer reformation described here was a repair process of cells stripped of the S-layer and, thus, probably reflected conditions quite different from the incorporation of S-layer domains in an existing lattice during cell growth.

No specific biological significance of the S-layer lattice from lactobacilli has been detected so far. In $L$. helveticus ATCC 12046 the S-layer appeared as a thin layer completely covering the thick peptidoglycancontaining layer. Since no morphological changes of the cells could be detected after removal of the S-layer with $\mathrm{LiCl}$ and during subsequent cell growth and S-layer reformation, a cell-shape-determining function of the crystalline array (Beveridge, 1988; Sleytr \& Messner, 1988) can be excluded. Previous studies on the permeability properties of S-layers from mesophilic and thermophilic Bacillaceae (Sàra \& Sleytr, 1987; Sàra et al. 1990) have shown that S-layers have the potential to function as selective molecular sieves. S-layers preventing the entry of molecules with molecular masses exceeding $10000-15000 \mathrm{kDa}$ could provide the organism with a selective advantage, since most lytic enzymes present in natural habitats have larger molecular masses (Stewart et al., 1986; Glenn, 1976). Since the S-layer of $L$. helveticus could not protect the peptidoglycan from lysozyme $\left(M_{\mathrm{r}} 14600\right)$ and mutanolysin $\left(M_{\mathrm{r}} 24000\right)$ it can be concluded from the molecular dimensions of these enzymes that the pores in the oblique S-layer lattice must be larger than $3.5 \mathrm{~nm}$ (Sàra et al., 1990). Further studies will show if the S-layer can protect the cells from proteases which generally have molecular masses larger than common muramidases. Only a few molecules of polycationized ferritin were adsorbed on whole cells of $L$. helveticus showing that the S-layer surface did not exhibit a net negative charge. The same observations were made with different Clostridium (Sàra et al., 1988) and Bacillus (Pum et al., 1989) species. Therefore, the functional role of the S-layer of $L$. helveticus could be to mask the underlying strongly negatively charged peptidoglycancontaining layer, as has been proposed previously for mesophilic and thermophilic Bacillaceae (Sàra et al., 1988; Sàra et al., 1990; Sleytr \& Messner, 1988). Further study on the interaction of $L$. helveticus ATCC 12046 with environmental components such as milk proteins will help to elucidate this functional aspect.

Part of this work was done during a visit by S.L. to the Zentrum für Ultrastrukturforschung, Vienna, Austria, which was supported by grants from INRA and from the Fonds zur Förderung der Wissenschaftlichen Forschung and Bundesministerium für Wissenschaft und Forschung in Osterreich. The kindness and excellent technical assistance of Ms Andrea Sheberl and Mrs Jutta Frank were particularly appreciated by S.L., as well as the numerous interesting discussions about cheese, bacteria and humans with Seta Küpçü. 


\section{References}

Accolas, J. P., Hemme, D., Desmazeaud, J. M., Vassal, L., Boullane, C. \& Veaux, M. (1980). Les levains lactiques thermophiles: propriétés et comportement en technologie laitière. Lait 60 , 487-517.

BADDILEY, J. \& DAVison, J. L. (1961). The occurrence and location of teichoic acids in lactobacilli. Journal of General Microbiology 24, 295-299.

BARKer, D. C. \& THORNe, K. J. (1970). Spheroplasts of Lactobacillus casei and the cellular distribution of bactoprenol. Journal of Cell Science 7, 755-785.

BEVERIDGE, T. J. (1981). Ultrastructure, chemistry and functions of the bacterial cell wall. International Review of Cytology 72, 229-317.

BEVERIDGE, T. J. (1988). The bacterial surface: general considerations towards design and function. Canadian Journal of Microbiology 34, 363-372.

De Man, J. C., Rogosa, M. \& Sharpe, E. (1960). A medium for the cultivation of lactobacilli. Journal of Applied Bacteriology 23, 130-135.

GlenN, A. R. (1976). Production of extracellular proteins by bacteria. Annual Review of Microbiology 30, 41-62.

GRUBER, K. \& SLEYTR, U. B. (1988). Localized insertion of new S-layer during growth of Bacillus stearothermophilus strains. Archives of Microbiology 149, 485-491.

GrUber, K. \& Sleytr, U. B. (1991). Influence of an additional proteinaceous layer (S-layer) on surface properties of Bacillus stearothermophilus. Archives of Microbiology 156, 181-185.

Howard, L. W., Dalton, D. D. \& MCCoubry, W. K. (1982). Expansion of the tetragonally arrayed cell wall protein layer during growth of Bacillus sphaericus. Journal of Bacteriology 149, 748-757.

IKAWA, M. \& SNELL, E. E. (1960). Cell wall composition of lactic acid bacteria. Journal of Biological Chemistry 235, 1376-1382.

KANDLER, O. \& KöNIG, H. (1985). Cell envelopes of archaebacteria. In The Bacteria, vol. 8: Archaebacteria, pp. 413-457. Edited by C. R. Woese and R. S. Wolfe. New York: Academic Press.

Kawata, T., Masuda, K., Yoshino, K. \& Fujmoto, M. (1974). Regular array in the cell wall of Lactobacillus fermenti as revealed by freeze-etching and negative staining. Japanese Journal of Microbiology 18, 469-476.

Kistler, J., AEBI, U. \& Kellenberger, E. (1977). Freeze-drying and shadowing a two-dimensional periodic specimen. Journal of Ultrastructural Research 59, 76-86.

KovaL, S. F. (1988). Paracrystalline protein surface arrays on bacteria. Canadian Joumal of Microbiology 34, 407-414.

lortal, S., Rousseau, M., Boyaval, P. \& van Heijenoort, J. (1991). Cell wall and autolytic system of Lactobacillus helveticus ATCC 12046. Journal of General Microbiology 137, 549-559.

LuCKevitch, M. D. \& Beveridge, T. J. (1989). Characterization of a dynamic S-layer on Bacillus thuringiensis. Journal of Bacteriology 171, 6656-6667.
Masuda, K. \& Kawata, T. (1979). Ultrastructure and partial characterization of a regular array (RA) in the cell wall of Lactobacillus brevis. Microbiology and Immunology 23, 941-953.

MASUDA, K. \& KAWATA, T. (1980). Reassembly of a regularly arranged protein in the cell wall of Lactobacillus brevis and their reattachment to cell walls. Microbiology and Immunology 24, 299-308.

MasudA, K. \& Kawata, T. (1981). Characterization of a regular array in the wall of Lactobacillus buchneri and its reattachment to the other wall components. Journal of General Microbiology 124, 81-90.

MasudA, K. \& KAWATA, T. (1983). Distribution and chemical characterization of regular arrays in the cell wall of strains of the genus Lactobacillus. FEMS Microbiology Letters 20, 145-150.

Masuda, K. \& KaWATA, T. (1985). Reassembly of a regularly arranged protein in the cell wall of Lactobacillus buchneri and its reattachment to cell walls: chemical modification studies. Microbiology and Immunology 29, 927-938.

Messner, P. \& SleyTR, U. B. (1992). Crystalline bacterial cell surface layers (S-layers). Advances in Microbial Physiology 33, (in the Press).

Messner, P., Hollaus, F. \& Sleytr, U. B. (1984). Paracrystalline cell wall surface layers of different Bacillus stearothermophilus strains. International Journal of Systematic Bacteriology 34, 202-210.

Pum, D., SÀra, M. \& SleyTr, U. B. (1989). Structure, surface charge and self-assembly of the S-layer lattice from Bacillus coagulans E38-66. Journal of Bacteriology 171, 5296-5303.

SÀrA, M. \& SLEYTR, U. (1987). Molecular sieving through S-layers of Bacillus stearothermophilus strains. Journal of Bacteriology 169, 4092-4098.

SÀra, M., Kalsner, I. \& Sleytr, U. B. (1988). Surface properties from the S-layer of Clostridium thermosaccharolyticum D120-70 and Clostridium thermohydrosulfuricum L111-69. Archives of Microbiology 149, 527-533.

Sàra, M., Moser-Thier, K., Kainz, O. \& Sleytr, U. B. (1990). Characterization of S-layers from mesophilic bacillaceae and studies on their protective role towards muramidases. Archives of Microbiology 153, 2096-2114.

SleytR, U. B. \& Messner, P. (1983). Crystalline surface layers on bacteria. Annual Review of Microbiology 37, 311-339.

Sleytr, U. B. \& MESSNER, P. (1988). Crystalline surface layer in procaryotes. Journal of Bacteriology 170, 2891-2897.

SMIT, J. (1986). Protein surface layers of bacteria. In Bacterial Outer Membranes as Model Systems, pp. 343-376. Edited by M. Inouye. New York: John Wiley and Sons.

Stewart, M., BeVeridge, T. J. \& Trust, T. J. (1986). Two patterns of Aeromonas salmonicida A-layer may reflect a structural transformation that alters permeability. Journal of Bacteriology 166, 120-127.

Turner, K. W., Morris, H. A. \& Martley, F. G. (1983). Swiss type cheese. II. The role of thermophilic lactobacilli in sugar fermentation. New Zealand Journal of Dairy Science Technology 18, 117123.

Williams, R. A. D. (1971). Cell wall composition and enzymology of lactobacilli. Journal of Dental Research 5, 1104-1115. 